\title{
Ekokrytyczne czytanie powieści Vladana Desnicy
} Pronalazak Athanatika*

\section{Goran Đurđević}

\author{
* Dziękuję Dariji Đurđević i prof. \\ dr. sc. Jožici Čeh Stergar za pomoc \\ przy zbieraniu literatury, Vinkovi \\ Tadiciovi za cenne rady, zwłaszcza \\ przy literaturze historycznej oraz doc. \\ dr sc. Suzani Marjanić i doc. dr sc. \\ Mirandi Levant-Peričić za wyjątkową \\ pomoc przy formułowaniu koncepcji, \\ a także anonimowym recenzentom \\ i redaktorom za konstruktywne \\ i życzliwe rady oraz cierpliwość.
}

\section{Wstęp}

Lata siedemdziesiąte XX wieku otwierają nowe perspektywy oraz ogląd na świat człowieka i człowieczeństwo. Społeczno-polityczny kontekst tych przemian sięga wydarzeń z 1968 roku, demonstracji studenckich, narastającej dekolonizacji i wyzwolenia krajów Trzeciego Świata. Wiąże się też ze sprzeciwem wobec interwencji USA w Wietnamie oraz z obawami przed możliwym konfliktem nuklearnym między rywalami z czasów zimnej wojny, a także kryzysem naftowym (energetycznym). Wydarzenia te, w połączeniu z rozwojem technologicznym, opartym na postępie nauk przyrodniczych i technicznych, pojawieniem się licznych wynalazków ułatwiających życie codzienne oraz szybkim nastaniem społeczeństwa konsumpcyjnego, otwierają nowe pola do kreowania świata, podążają za ówczesnymi wyzwaniami i problemami. Pojawiły się i rozpoczęły swą działalność ruchy ekologiczne (zielonych), feministyczne (dotyczące płci i kobiet), pacyfistyczne (antywojenne) oraz inne. Grupy te postrzegają codzienność w odmienny sposób i otwierają pole na nowe tematy, wprowadzając do postmodernizmu. W ponowoczesności otwiera się droga m.in. na studia kulturowe, kulturę popularną, ekokrytykę/ekokrytycyzm ${ }^{1}$, ekofeminizm, lingwistyczny zwrot, analizę dyskursu i na wiele innych subdyscyplin, kierunków badawczych oraz innowacji teoretyczno-metodologicznych ${ }^{2}$.

\footnotetext{
${ }^{1}$ W pracy konsekwentnie posługuję się terminem ekokrytyka, który w swoich pracach wykorzystywała Suzana Marjanić, a nie ekokrytycyzm, jak proponował Domagoj Brozović. Por. Suzana Marjanić, „Književni svjetovi s etnološkom, ekološkom i animalističkom nišom", Narodna umjetnost, 43, nr 2 (2006): 163-186; Suzana Marjanić, „Zoosfera Tita Andronika: ljudska, previše ljudska bestijalnost”, Treća, 10, nr 2 (2008): 59-82; Domagoj Brozović, „Čitati zeleno. Ekokriticizam - neprepoznata mogućnost suvremene hrvatske znanosti o književnosti”, Književna smotra, 44, nr 164-165 (2012): 29-35.

${ }^{2}$ W licznych tytułach o zmianach w różnych aspektach rzeczywistości społecznej lat siedemdziesiątych por. Thomas Borstelmann, The 1970s. A New Global History from Civil Rights to Economic Inequality (Princeton: Princeton University Press, 2015); The Shock of the Global. The 1970s in Perspective, red. Niall Ferguson i in. (Harvard: Harvard University Press, 2011).
} 
Ekokrytyka, jako jeden z nowszych sposobów ujmowania nowoczesności, otworzyła różne perspektywy analizy kultury - zwłaszcza literatury i sztuk wizualnych - w kontekście środowiska. Pojęcie ekokrytyki zostało sformułowane przez Williama Rueckerta w jego artykule z 1978 roku Literature and Ecology: An Experiment in Ecocriticism. Definiował ją jako połączenie koncepcji ekologicznych i literatury ${ }^{3}$. Pierwszą ideę połączenia przyrody i literatury, według Petera Berry'ego i Domagoja Brozovicia, wprowadził Karl Kroeber w pracy „Home at Grasmere": Ecological Holiness, wydanej jeszcze w 1974 roku4.

Cheryll Glotfelty, redaktorka monografii The Ecocriticism Reader. Landmarks in Literary Ecology, przedstawia następującą definicję:

Ekokrytyka to badanie związku między literaturą a środowiskiem fizycznym. Tak jak krytyka feministyczna bada język i literaturę z perspektywy świadomości płci, a krytyka marksistowska wprowadza świadomość o metodach produkcji oraz klas w wymiarze ekonomicznym do lektury swoich tekstów, tak ekokrytyka przyjmuje geocentryczne podejście do studiów literackich... Ekokrytyka podziela fundamentalne założenie, że kultura człowieka jest powiązana ze światem fizycznym, oddziałuje na niego, a on wpływa na nią. Ekokrytyka za swój temat przewodni obiera wzajemne powiązania przyrody i kultury, zwłaszcza kulturowych artefaktów języka i literatury...5.

Subdyscyplina rozwija się od końca lat osiemdziesiątych, a szczególnie intensywnie w latach dziewięćdziesiątych i dwutysięcznych, kiedy formowano stowarzyszenia (ASLE ${ }^{6}$ i EASL$\mathrm{CE}^{7}$ ) oraz gdy powstawały czasopisma i monografie. Amerykańska ekokrytyka skupia się na dziewiętnastowiecznych autorach i ich opisach natury (interpretacjach dzikiej przyrody, krajobrazów, motywów i tematów), co oznacza powrót i celebrację natury jako takiej. Natomiast Brytyjczycy są bardziej zorientowani na związek kultury i przyrody poprzez pryzmat antropocentrycznych zagrożeń dla tej drugiej (lub środowiska). Ważnym wyzwaniem, zdaniem Domagoja Brozovicia, jest z pewnością brak bardziej reprezentatywnej literatury metodologicznej i terminologicznej ${ }^{8}$, praktyk i paradygmatów. Jedno z kluczowych pytań brzmi: kto lub co znajduje się w centrum ekokrytycznej lektury dzieł literackich: człowiek czy przyroda? Ekokrytycy interpretują naturę i kulturę jako fenomen, a nie jako językowe, sztuczne konstrukcje ${ }^{9}$.

${ }^{3}$ William Rueckert, „Literature and Ecology: An Experiment in Ecocriticism”, w Ecocriticism Reader. Landmarks in Literary Ecology, red. Cheryll Glotfelty, Harold Fromm (Athens, Georgia: The University of Georgia Press, 1996), 107.

${ }^{4}$ Peter Barry, Beginning Theory. An Introduction to Literary and Cultural Theory (Manchester-New York: Manchester University Press, 2009), 240; Brozović, Čitati zeleno, 29. Por. też Karl Kreober, „'Home at Grasmere’: Ecological Holiness”, Publications of the Modern Language Association of America, 89, nr 1 (1974): 132-141.

${ }^{5}$ Cyt. wg Brozović, Čitati zeleno, 30. Por. też Cheryll Glotfelty, „Introduction: Literary Studies in an Age of Environmental Crisis", w Ecocriticism Reader. Landmarks in Literary Ecology, red. Cheryll Glotfelty, Harold Fromm (Athens, Georgia: The University of Georgia Press, 1996), 107.

${ }^{6}$ Dane organizacji Association for the Study of Literature and Environment są dostępne na stronie https://www.asle.org.

${ }^{7}$ Dane organizacji European Association for Study of Literature Culture and Environment są dostępne na stronie https://www.easlce.eu.

${ }^{8} \mathrm{~W}$ ostatnim czasie poczyniono znaczące zmiany na tym polu, co widoczne jest w pracach Dereka Gladwina i Simona C. Estoka. Por. Derek Gladwin, „Ecocriticism”, Oxford Bibliographies (http://www.oxfordbibliographies. com/view/document/obo-9780190221911/obo-9780190221911-0014.xml); Simon C. Estok, „Teorija s ruba: životinje, ekokritika, Shakespeare”, Kazalište, 11, nr 35-36 (2008): 84-97 (zob. obszerną bibliografię).

${ }^{9}$ Por. Brozović, Čitati zeleno, 29-35. 
Relacja natury i kultury ukształtowana w ekokrytycznych czytaniach dzieł literackich jest przyczynkiem do analizy powieści Vladana Desnicy Pronalazak Athanatika. Pierwotny pomysł pisarza o lekarstwie na nieśmiertelność i przemianach, jakie zachodzą w świecie, jest dobrą podstawą do odczytania wzajemnych relacji kultury i przyrody oraz obserwacji tej drugiej jako podmiotu, a nie tylko jako zmarginalizowanego tematu.

Niniejsza praca jest pomyślana jako kolaż trzech części tematycznych: ekokrytycznego podejścia do życia - śmierci - nieśmiertelności przez porównanie i powiązanie niedokończonej powieści Desnicy z dziełem Homo deus. Następna część dotyczy ekokrytycznej analizy deszczu przez pryzmat koncepcji Susan Farrell; analizy powieści Pronalazak Athanatika w kontekście dystopijnych powieści ekologicznych/dotyczących środowiska we współczesnej literaturze chorwackiej: Planet Friedman Josipa Mlakicia i Mjesečev meridijan Edo Popovicia wraz z porównaniem ekokrytycznego czytania koncepcji antropocenu autorki Louise Squire.

\section{2. Życie - śmierć - nieśmiertelność: powieść Pronalazak Athanatika w ujęciu ekokrytycznym}

Już w czasach prehistorycznych ludzie stworzyli binarny system składający się z życia i śmierci. O ile pierwszy element tego systemu można było jasno rozpoznać przez narodziny człowieka i samo życie, o tyle drugi - śmierć - pozostał zagadką, mistyczną i nieokiełznaną. $\mathrm{Z}$ tych powodów w wielu mitach, religiach, sztuce i dziełach literackich pojawia się opowieść o nieśmiertelności i poszukiwaniu jej jako swoistego zwycięstwa nad śmiercią ${ }^{10}$ W niektórych mitologiach nieśmiertelność kojarzy się z określonymi roślinami, charakterem przyrody (górami, morzem, nieznanymi lądami) czy życiem bohaterów i bogów ${ }^{11}$. Jednakże większość religii monoteistycznych postrzega śmierć jako kontynuację życia w innym świecie, w zależności od okoliczności i ziemskiego życia danej osoby ${ }^{12}$. Współcześnie, w XXI wieku, koncepcja nieśmiertelności jest aktualizowana. Dzisiaj nieśmiertelności nie doświadcza się poprzez odnalezienie konkretnego kwiatu lub liścia wybranej rośliny, zjedzenie określonych pokarmów (owoców lub warzyw) lub przez podróż w góry lub nieznane kraje - jak to wyobrażano sobie w przednowoczesnym świecie. Przedłużanie ludzkiego życia odbywa się poprzez wykorzystanie możliwości technologicznych, w tym powiązanie ze sztuczną inteligencją, wynalazkami, robotami i podobnymi nowinkami.

\footnotetext{
${ }^{10}$ Por. Jacques Choron, „Death and Immortality”, w Dictionary of the History of Ideas, red. Philip P. Wiener, t. 1 (New York: Charles Scribner's Sons, 1974), 635-646 (https://web.archive.org/web/20070311081839/http:// etext.lib.virginia.edu/cgi-local/DHI/dhi.cgi?id=dv1-76).

${ }^{11} \mathrm{Na}$ przykład Ep o Gilgamešu lub Putovanje na zapad pokazują wyobrażenia o poszukiwaniu nieśmiertelności w mitologii sumerskiej, chińskiej. Problem zjawiska nieśmiertelności w mitologii greckiej uwypuklony jest w micie o Syzyfie i schwytaniu boga Tanatosa, które zatrzymało umieranie ludzi, dopóki bóg nie został uwolniony. Por. Reginald Campbell Thompson, The Epic of Gilgamesh: Complete Academic Translation, translated from cuneiform tablets in the British Museum literally into English hexameters, London 2007; Wu Cheng'en, A journey to the West (Beijing: Foreign Languages Press, 1955); „Sisyphus”, Encyclopaedia Britannica (https://www.britannica.com/topic/Sisyphus).

${ }^{12} \mathrm{~W}$ chrześcijaństwie objawia się to w idei życia pozagrobowego i wizji raju, czyśćca (który uznają katolicy) i piekła, podczas gdy w islamie odnajdujemy podobną koncepcję dla raju (džennet)) i piekła (džehennem), a w judaizmie raju (shamayin) i piekła (gehenna). Podobne koncepcji są w religiach wschodnich: buddyzmie i hinduizmie, np. z różnym rozumieniem piekła, spośród których najbardziej znana jest naraka. Szczegółowiej o życiu pozagrobowym zob. „Zagrobni život”, Hrvatska enciklopedija (http://www.enciklopedija.hr/natuknica. aspx?id=66705).
} 
Drugi element w tej binarnej parze, nawiązujący do pierwszego, czyli dążenie człowieka do nieśmiertelności, jest fundamentalnym pytaniem ekokrytyki, stworzonym we (współ)relacji kultury i przyrody. Ich dychotomię najlepiej określa William Howarth, definiując ekokrytyka/ ekokrytyczkę jako „osobę, która analizuje wady i zalety opisów ukazujących wpływ kultury na przyrodę z zamiarem gloryfikowania, krytykowania jej eksploatacji i naprawienia szkód wyrządzonych przez aktywność polityczną"13.

Pisarz Vladan Desnica w swoich dziełach wielokrotnie poruszał problematykę śmierci i nieśmiertelności, czyniąc z nich główny temat, a najbardziej wyraziście przedstawił je w niedokończonej powieści Pronalazak Athanatika. Ta krótka powieść ma strukturę dialogu między narratorem i Krezubogiem, znajomym narratora, przedstawiającym swoją nową koncepcję, a dokładniej fabułę nienapisanej powieści. Akcja rozgrywa się w bliżej nieokreślonej przyszłości (autor używa określenia „kilka wieków naprzód” ${ }^{14}$ ), w nienazwanym i nieznanym kraju, w którym dochodzi do wynalezienia leku (szczepionki) przeciwko śmierci.

Należy podkreślić decyzje terminologiczne Desnicy, jak zauważa Krešimir Nemec, ponieważ pisarz konsekwentnie używa następujących terminów: lekarstwo, hormon lub czynnik Iks zamiast eliksir, by określić wynalazek athanatik (którego sama nazwa wskazuje, czego dotyczy: athanatos - przeciwko śmierci), oraz określeń wieczna regeneracja lub nieskończony czas trwania zamiast nieśmiertelność ${ }^{15}$. Dzięki temu akcentuje naukowe pochodzenie leku - zresztą wyraźnie stwierdza, że lek jest wynikiem badań naukowych - odcinając się w ten sposób od tradycyjnych podejść do nieśmiertelności i poszukiwań eliksirów.

W dalszej części akcji widoczne są konsekwencje społeczne i gospodarcze. Na samym początku wynalazek wywołał niespotykaną euforię, radość i celebrację, które wkrótce, wraz z wprowadzeniem nadzoru państwowego, zaczęły się zmieniać. Okazało się bowiem, że nie każde życie jest równie cenne. O nieśmiertelności decydował specjalny urząd Izuzeća od smrti (Zwolnienia od Śmierci), który dokonał segregacji grup społecznych (klas) w celu przydzielania athanatiku. Segregacja ma układ piramidalny i hierarchiczny, jest mocno powiązana z aktualną pozycją władzy, począwszy od prezydenta i premiera aż po niższe szczeble. Ta zasada została w powieści uzasadniona powszechnym problemem środowiska: brakiem wystarczającej ilości żywności. Wprowadzone środki prowadzą do nasilenia przemocy, kradzieży, oszustw, zabójstw, zamieszek i rewolucji. Rezultatem jest powstanie totalitarnego państwa dyktatora Maman-Mammona, które kontroluje życie i śmierć swoich obywateli. Wkrótce potem nastąpiły zabójstwa, konflikty i ponowne wykorzystanie komór gazowych oraz podział ludzi na dwie większe grupy: śmiertelnych i nieśmiertelnych. Chociaż lek udoskonalono na dwa podtypy - A (który działał na wszystkie rodzaje śmierci, w tym nagłe) i B (który działał tylko w przypadku śmierci naturalnej) - nie poprawiło to sytuacji, ponieważ brak pożywienia i konsekwencje przyjmowania specyfiku (zaburzenia) spowodowały dalsze problemy. Zakończenie skutkowało świadomym zniszczeniem medykamentu, czyli wybrania przez ludzkość śmiertelności zamiast nieśmiertelności.

\footnotetext{
${ }^{13}$ William Horwath, „Some Principles of Ecocriticism”, w Ecocriticism Reader. Landmarks in Literary Ecology, red. Cheryll Glotfelty, Harold Fromm (Athens, Georgia: The University of Georgia Press, 1996), 69. Por. też Tjaša Trček, „Ekokritika - upodobitve narave v izbranih mladinskih delih”, diplomski rad, Univerza v Ljubljani, Pedagoška fakulteta, 2016, 3.

${ }^{14}$ Vladan Desnica, Pronalazak Athanatika (Zagreb: V.B.Z., 2006), 8.

${ }^{15}$ Krešimir Nemec, „Pronalazak Athanatika - između utopije i distopije”, w Desnica, Pronalazak Athanatika, 87.
} 
O aktualności tego tematu na początku XXI wieku świadczy również pojawienie się światowego bestsellera słynnego izraelskiego historyka Yuvala Noaha Harariego i jego dzieła Homo deus o bardzo znaczącym podtytule A brief history of tomorow [pol. wyd. Krótka historia jutra]. Jest to swego rodzaju kontynuacja jego poprzedniego sukcesu Sapiens z podtytułem A brief history od humankind [pol. wyd. Od zwierzq̨ do bogów. Krótka historia ludzkości]. W Sapiens Harari przez pokazanie czterech rewolucji - poznawczej, rolniczej, unifikacyjnej i naukowej [w polskim wydaniu znajdują się trzy, bez unifikacyjnej - przyp. tłum.] - wyjaśnił, że w przeszłości człowiek osiągnął swój obecny poziom, natomiast w Homo deus zajął się problemami przyszłości ${ }^{16}$. W części wprowadzającej autor przedstawia krótki przegląd historii poprzez wizję zwycięstwa ludzi nad wojną (stwierdza, że samobójstwo jest bardziej prawdopodobne niż śmierć na wojnie), głodem (na świecie jest więcej otyłych niż głodnych) i chorobami (większość chorób zakaźnych i epidemii została zwalczona). W tej części książki, jak podkreśla Tizian Raspor, dominuje ton optymistyczny ${ }^{17}$. W pierwszym rozdziale Harari przedstawia przeszłość człowieka jako najpotężniejszej istoty na planecie, od początków Homo sapiens do współczesności. Podobnie jak w książce Sapiens, autor wyjaśnia to przez stworzenie kolektywnej wyobraźni zbiorowej, która przeradza się w mity, pozwalając na uformowanie wspólnoty złożonej z nieznanych sobie osób. Taka imaginacja umożliwiała kreowanie narodów, pieniędzy, religii, praw człowieka, przepisów i tym podobnych. Wśród swoich tez wyróżnia koncepcję algorytmu jako swego rodzaju źródła wniosków i podejmowania decyzji (zamiast posługiwania się intuicją). W drugiej części idzie o krok dalej, ukazując niemożliwą do pogodzenia różnicę między władzą a rozsądkiem, stwierdzając, że poprzez wybór władzy jednostka zbliża się do statusu bóstwa (w religiach tradycyjnych), ponieważ potrafi kontrolować i koordynować różne procesy. W ostatnim rozdziale wprowadza ideę dataizmu (religii danych) jako nowej „religii” hołdującej sile i znaczeniu informacji oraz projekcji przyszłości zgodnie z nowymi postępami technologicznymi, określając, jakie to będzie miało konsekwencje w ruchach społecznych, z możliwym dalszym wzrostem nierówności społecznych ${ }^{18}$.

Najważniejszy podrozdział dotyczący tego tematu nosi tytuł The Last Days of Death. Harari zarysowuje w nim swoją tezę o nieśmiertelności. Opisuje świętości ludzkiego życia widoczną w wielu aktach prawnych i legislacyjnych, a także w życiu codziennym. Jednak zauważa, że religie (chrześcijaństwo, hinduizm, judaizm) mają inne spojrzenie na śmierć, ponieważ bez niej cała koncepcja tych wspólnot - obejmująca niebo, piekło i reinkarnację - traci sens. Współczesny człowiek, według Harariego, umiera z powodu problemów technicznych - serce przestaje bić, dochodzi do zatoru tętnicy, komórki rakowe rozrastają się w organizmie, ponieważ serce nie otrzymuje powietrza albo z powodu genetycznej mutacji komórek.

Jego tezę o śmierci najlepiej streszcza następujące zdanie: „Jeśli tradycyjna śmierć była specjalnością księży i teologów, dziś sprawę przejęli inżynierowie”19. Uważa, że zawsze w tle

${ }^{16}$ Yuval Noah Harari, Sapiens. Kratka povijest čovječanstva (Zagreb: Fokus komunikacije, 2015). Por. też Goran Đurđević, „Yuval Noah Harari, Sapiens: kratka povijest čovječanstva, Fokus, Zagreb 2015, 479”, Historijski zbornik, 68, nr 1 (2015): 203-205.

${ }^{17}$ Tizian Raspor, Yuval Noah Harari, Homo deus. Kratka povijest sutrašnjice, prevela s engleskog Marija Perišić, Fokus komunikacije Zagreb 2017, 461, Historiografija.hr, http://www.historiogra'ja.hr/?p=5663.

${ }^{18}$ Yuval Noah Harari, Sapiens. Por. też Đurđević, „Yuval Noah Harari, Sapiens. Kratka povijest čovječanstva”, 177-178.

${ }^{19}$ Harari, Sapiens, 28. 
istnieje problem techniczny, nawet przy złych warunkach pogodowych, wypadkach samochodowych i innych nieszczęściach, które powodują śmierć. Przekonuje, że wyszukiwarka internetowa i jedna z najpotężniejszych korporacji, Google, zainwestowały znaczące środki na badania śmierci i walkę z nią, zatrudniając dwóch wybitnych naukowców i "promotorów” nieśmiertelności - Raya Kurzweila i Billa Marisa. Jednocześnie Google nie jest jedyną firmą z Doliny Krzemowej, która inwestuje w tego typu badania. Nieśmiertelność będzie generować różnorodne zmiany społeczne dotyczące wyborów zawodowych, przebiegu kariery, małżeństw i struktury rodziny, rodzicielstwa. Harari kończy rozdział ostrzeżeniami przed tym, co może się wydarzyć, gdy nauka stworzy warunki do nieśmiertelności. Rysuje wizje konfliktów, wojen i wzajemnej walki o nieśmiertelność, które rzucą cień na dotychczasowe konflikty. To w nich lęk przed śmiercią zostanie zastąpiony wojnami, czyli walką o nieśmiertelnośćc ${ }^{20}$.

Porównując tych dwóch autorów, Desnicę i Harariego, zauważamy, że niezależnie od czasu powstawania ich prac piszą o tym samym problemie, z podobnego punktu widzenia, choć z różnym skutkiem. Obaj piszą o nieśmiertelności jako fenomenie przyszłości opartym na nauce i technologii, przy czym już pierwsze różnice powstają na tym właśnie polu: Desnica dostrzega źródło nieśmiertelności w medycynie, według Harariego nieśmiertelność to postęp technologiczny (operacje transplantologiczne dzięki rozwojowi robotyki i przyrządów technologicznych dla zdrowia). Koncepcja lekarstwa na nieśmiertelność przypomina łączenie tradycyjnych wyobrażeń o zdobyciu nieśmiertelności (lecznicze zioła lub określona żywność) z osiągnięciami czasów współczesnych (wynalazkiem leków). Innymi słowy, Desnica traktuje problem nieśmiertelności i śmiertelności jako rodzaje chorób i wyobraża sobie, jakie zdarzenia i konsekwencje przyniosłoby wynalezienie prewencyjnego środka na zniknięcie śmiertelności, czyli zapobieganie umieraniu. Podejście Harariego jest podobne do podejścia współczesnych inżynierów. Postrzega ludzkie ciało jako mechanizm z częściami o określonym terminie przydatności, które podlegają wymianie, czyniąc ten mechanizm mniej lub bardziej trwałym. W postrzeganiu nieśmiertelności Desnica w ciekawy sposób powiązał tradycję (wyjątkowy preparat, który nazywa lekiem) i podejście naukowe (systematyczne badania, wynalazek). Tym samym stał się mostem łączącym tradycję i najnowsze podejście reprezentowane przez Harariego. W książce Pronalazak Athanatika widoczny jest kontrast między lekiem a wynalazkiem. Lek na nieśmiertelność zawsze jest produktem technologiczno-naukowej pracy, a tym samym w idei (i realizacji) jest daleki od tradycyjnego poszukiwania w przyrodzie (przez wybór konkretnej rośliny, podróż do odległych, egzotycznych i nieznanych krajów). To odchylenie, mimo że częściowo oparte na tradycji (bo mowa jest o preparacie), pokazuje, jak bardzo człowiek, planując i realizując athanatik, oddalił się od przyrody jako całości zjawiska, w którym żyje i działa, a jak stał się hegemonem.

Wspólne dla obojga autorów jest to, że postrzegają śmiertelność jako problem naukowo-techniczny, który można rozwiązać wraz z rozwojem nauki i technologii. Podejście do śmierci jako choroby, defektu technicznego i przewidywanie, że rozwiązanie istnieje w takiej interpretacji zjawisk, sugeruje wykluczanie człowieka (którego cykl życia jest ograniczony przez narodziny, życie i śmierć) z przyrody przez stawianie go w pozycji dominującego, władcy, który znajduje sposób na przedłużenie życia i wykluczenie śmiertelności. Inne istoty żywe nie mają tej

${ }^{20}$ Harari, $25-30$. 
możliwości, co dodatkowo izoluje człowieka i zaburza relacje z naturą, pokazując jego uprzywilejowanie i tworząc antagonizm między człowiekiem a innymi (mam tu na myśli wszystkie żywe i nieożywione istoty oraz przyrodę). Oczekiwania, jakie żywili ludzie u szczytu osiągnięć kulturowych i naukowych oraz nieśmiertelność, doprowadziły do niespodziewanego wyobcowania od natury (a tym samym człowieka), co w konsekwencji zakłóciło relację z nią (podobnie jak w społeczeństwie, które tworzy reżimy totalitarne).

Druga różnica, którą odnajdujemy, dotyczy samego rozumienia nieśmiertelności. U Desnicy wynalezienie dwóch typów athanatika (A i B) oznacza uwzględnienie różnych rodzajów śmierci - naturalnej i niespodziewanej (tj. nienaturalnej). Natomiast Harari zajmuje stanowisko wobec nienaturalnej śmierci, wierząc, że niektórzy ludzie zginą w wypadkach i konfliktach wojennych, dlatego posługuje się określeniem bezśmiertelny zamiast nieśmiertelny.

Trzecią część zamysłu autorów stanowi porównanie konsekwencji. Nieśmiertelność w powieści Desnicy ma charakter pesymistyczny, ponieważ zostaje zatracona równorzędność śmiertelności, co prowadzi do powstania wielkich różnic społecznych w strukturze władzy, a ostatecznie do wyłaniania się systemów totalitarnych, które przechodzą od kontroli życia do całkowitej kontroli życia i śmierci. Wymazuje to wszelką nadzieję na równoprawność (równość wobec śmierci i interpretowanie ziemskiego życia w odniesieniu do życia pozagrobowego dawało pocieszenie i nadzieję wielu religijnym mieszkańcom). Jednak w zakończeniu dzieła Desnica otwiera możliwość pozytywnego zakończenia, niezależnie od przywrócenia ludzkiej śmiertelności. Harari nieśmiertelność (jeden z fenomenów przyszłości) opisuje również w tonie pesymistycznym, ponieważ nie traktuje jej jako celu ostatecznego, lecz sposób na stworzenie Homo deusa z obecnego Homo sapiens. Nieśmiertelność wpisuje się w całość jako pierwsza część serii: nieśmiertelność, szczęście, boskość. Harari pokazuje, czym może być nieśmiertelność (i dla kogo): „Jeśli Kurzweil i de Gray mają rację, być może już niektórzy nieśmiertelni mogą chodzić obok nas na ulicy, zwłaszcza jeśli idziesz Wall Street lub Piątą Aleją ${ }^{21}$. Wzmacnia to rozwarstwienie społeczne wynikające $z$ istnienia nieśmiertelności, ponieważ ci, którzy mają najwięcej pieniędzy, będą w stanie sobie ten przywilej zapewnić. Również jako historyk dostrzega dotychczasowe tarcia i konflikty wewnątrz społeczeństw i państw, a także między poszczególnymi państwami i zakłada, że w walce o nieśmiertelność będą miały miejsce konflikty i wojny światowe.

Takie katastroficzne przewidywania zbiegają się u Harariego i Desnicy. Obaj postrzegają nieśmiertelność jako źródło nowych, jeszcze silniejszych i groźniejszych wojen, które swoją zaciekłością i znaczeniem przewyższą wszystkie dotychczasowe konflikty. W związku z tym pojawią się dodatkowe dyferencje społeczne o różnych skutkach. Desnica pisze o powstaniu reżimów totalitarnych, a Harari zakłada wybuch wojny o trudnym do przewidzenia zakończeniu, ponieważ obok obecnej nierówności ekonomicznej pojawi się i biologiczna. W pesymizmie obu autorów można odczytać konsekwencję odejścia od natury. W stworzonej dychotomii kultury i przyrody, w obu analizowanych utworach kultura traktowana jest jako nadrzędna. Pierwotna idea człowieka jako nieśmiertelnego, stwórcy i władcy (w powieści Homo deus) jest w swej koncepcji nienaturalna. Wychodząc od samej idei niezgodnej z naturą, jej

\footnotetext{
${ }^{21}$ Harari, 27.
} 
realizacja musi skończyć się również konsekwencjami przeciwko naturze, gdyż oba systemy (reżimy totalitarne, wydarzenia wojenne) implikują istnienie hegemonów (ludzi, czyli części elity politycznej, militarnej i ekonomicznej) nad innymi/Innymi (resztą rasy ludzkiej, ale też wszystkich innych stworzeń i samej przyrody).

Analiza porównawcza tych dwóch dzieł doprowadza nas do oceny finalnej części samych dzieł. Obaj autorzy pozostawiają możliwość pozytywnego zakończenia, czyli wybrania optymistycznej drogi dla przyszłości. Podzielają humanistyczny światopogląd, w który należy włączyć naukę i osiągnięcia naukowe. Harari widzi wybór właściwej ścieżki we wspólnym globalnym zarządzaniu zamiast w dotychczasowych, narodowych rządach. Desnica kładzie nacisk na rozsądek i racjonalne rozwiązanie połączone z empatią jako odpowiedni kierunek dla przyszłości. Wybór pozytywnego rozwiązania i drogi, która zapobiegnie pesymizmowi i pogrążeniu się w dekadencji ludzkiej wyższości nad przyrodą i samowystarczalności, wiąże się bezpośrednio z rezygnacją z nieśmiertelności jako kulminacji nienaturalnego działania, które zaprzecza powiązaniom i połączeniu z naturą jako całością, którą tworzy człowiek razem z istotami żywymi i światem nieożywionym.

Dotychczasowe porównanie Desnicy i Harariego zostało sprowadzone do podejścia antropocentrycznego, w którym podstawą analizy była bezpośrednia społeczna konsekwencja (potencjalnej) nieśmiertelności. Innymi słowy analizowano komponent kulturowy (cywilizacyjny), zaniedbano podejście do środowiska i przyrody. Zależność między kulturą (cywilizacją) a naturą (środowiskiem) różni się w samych definicjach poszczególnych ekokrytyków ${ }^{22}$. Niezależnie od tego, jak interpretujemy tę relację, niewątpliwie ona istnieje.

W obu utworach przyroda nie jest wyraźnie nakreślona jako główny wątek, autorzy zajmują się społecznymi konsekwencjami nieśmiertelności. Przyroda jednak jest nie tylko dodatkiem, ale także istotnym czynnikiem tej wzajemności. Możemy się więc zastanawiać, na ile człowiek zdecydował się wyjść z naturalnego cyklu (który czyni razem ze światem ożywionym, a częściowo i nieożywionym), udowadniając swoją wyższość (jak pisze eksplicytnie Harari, stając się bogiem) i manifestują dążenie do nieśmiertelności. W ten sposób człowiek (a także jego stosunek do chorób, głodu i pokonywania klęsk żywiołowych) porzuca relacje z innymi żywymi istotami, stając się nadrzędnym elementem zewnętrznym. Powodzenie zwycięstwa nad śmiercią jako nieodłączną częścią natury i cyklem życiowym, przez który przechodzą wszystkie żywe istoty, przynosi zwycięstwo człowieka nad mistycznym i nieznanym, ale jednocześnie przyczynia się do zerwania łączności z naturą. Takie porzucenie kontaktu z przyrodą, przy jednoczesnym wzroście postępu technologicznego (Harari i Desnica nieśmiertelność łączą z przemysłem farmaceutycznym, robotyką i technologią), skutkuje rozpadem dotychczasowych, zakorzenionych stosunków społecznych, ale także powstaniem niezgodnego z naturą (a tym samym antyludzkiego) przenikania, relacji i zmian społecznych. Ostatecznie podporządkowanie wszystkiego, co dostępne rozwojowi, postępowi technologicznemu i naukowemu, a także wzrost kapitału, prowadzi do konfliktu z naturą, którego człowiek nie może wygrać, a wszyscy stają się przegranymi.

\footnotetext{
${ }^{22}$ Na przykład Greg Garrard uważa, że wyzwaniem ekokrytyki jest ciągłe pamiętanie o tym, w jaki sposób natura jest kulturowo zbudowana, a z drugiej strony, że istnieje. Por. Greg Garrard, Ecocriticisam (Abingdon: Routledge, 2004), 10.
} 
Do problemów ekologicznych wymagających zbadania należy związek między żywnością a środowiskiem i chorobami, ale także postrzeganie zwierząt. Desnica podkreśla, że żywność była największym problemem po wynalezieniu specyfiku athanatik, ponieważ Ziemia stała się niewystarczająca dla rosnącej liczby ludzi ${ }^{23}$. Tym samym nieśmiertelność stała się poważnym problemem ekologicznym. W ten sposób Desnica przeciwstawia podstawowe potrzeby i cechy istot żywych (odżywianie jako proces podtrzymujący życie i śmiertelność/nieśmiertelność), ukazując ich wzajemne powiązania i swoisty paradoks, ponieważ ludzie chcąc osiągnąć wyimaginowany ideał nieśmiertelności, ignorują wszystkie inne czynniki naturalnego cyklu, doprowadzając do braku pożywienia, jednej z podstawowych potrzeb życiowych jako warunku podstawowego do dalszego rozwoju. To droga do dystopii, w której próba panowania przez człowieka nad życiem i śmiercią (w postaci nieśmiertelności) nieuchronnie prowadzi do zniszczenia przyrody, destrukcji środowiska i dehumanizacji.

W powieści Desnicy zwierzęta są wymienione tylko dwa razy. Jako pierwszy, na samym początku powieści, wspomniany jest wilk jako jeden z wyznaczników życia w przeszłości:

Ludzkie słowa i lęki przychodzą i wychodzą z mody. Jaką rolę w dawnych czasach w myślach i uczuciach człowieka pełniło słowo wilk! Prawie całe życie upływało „pod znakiem wilka”! Kto dziś jeszcze myśli o wilku? Kto w dzisiejszych czasach myśli o likantropii? Dziś człowiek nie boi się już śmierci...2 ${ }^{24}$

Kolejna wzmianka to porównanie przemiany ludzi w czasach athanatiku w drapieżcę:

Powiedzieliśmy: ludzie stali się drapieżcami. A to znaczy, że przestały dla nich istnieć wszystkie prawa i obowiązki, wszelkie moralne i inne zasady, rozsądek, refleksja, uprzedzenia czy jakkolwiek to chcecie nazwać. Przyszli drapieżcy nie wiedzieli już, czym jest ocena sytuacji, kompromis, taktyka i ostrożność, jak oszczędzać siły i mądrze chronić siebie. Wpadli bezmyślnie w przepaść, ginęli jak muchy - ale ginęli. ${ }^{25}$

Odniesienie do wilka w tym przypadku wskazuje na średniowieczne wyobrażenia o wilkołakach, przerażających i wywołujących strach w przeszłości, który jednak zniknął wraz z wynalezieniem preparatu athanatik ${ }^{26}$. Porównanie ludzkiego zachowania do drapieżcy, użycie samego słowa drapieżca (w pierwotnym znaczeniu rzędu ssaków lądowych) jako metafory dla niezorganizowanej, dzikiej wspólnoty lub grupy osobników funkcjonujących w dystopii wynalazku i działania athanatiku, jest sprzeczne z normami społecznymi i zasadami postępowania. Wybierając to słowo, które ma silny symboliczny przekaz czegoś obcego ludziom, Desnica pokazuje konsekwencję niekontrolowanego rozwoju technologicznego w obrazie pesymizmu, łamania norm społecznych i beznadziei. Właśnie ze względu na zakłócenie naturalnej równowagi między ludźmi i innymi istotami (ponieważ ludzie zyskują nieśmiertelność, a tym samym stają się dosłownie i symbolicznie lepsi) odpowiedzią jest pesymistyczna dystopia, dla której pisarz pozostawia możliwość optymistycznego końca.

${ }^{23}$ Desnica, Pronalazak Athanatika, 21.

${ }^{24}$ Desnica, 8.

${ }^{25}$ Desnica, 62.

${ }^{26} \mathrm{O}$ wilkołakach, likantropii w kulturze popularnej w Chorwacji por. Ingrid Kirša, „Likantropija u popularnoj kultury", diplomski rad, Sveučilište u Zagrebu, Hrvatski studiji, Odsjek za kroatologiju, 2017. 
Vladan Desnica obrazuje wybrane stosunki społeczne jako choroby, które podlegają pewnym zasadom:

Tylko by przypadkiem pacjentowi się nie przytrafiło, by zamiast na raka umarł z powodu infekcji! Ponieważ między chorobami panuje dżentelmeńska umowa. Nie ma przechwycenia ani wychodzenia przed szereg. Wyjątkowo może się zdarzyć, by jakaś nowa choroba, która nie zna jeszcze panujących reguł, przekracza granicę. Ale natychmiast klepną ją po ramieniu, ponieważ tu panuje idealny szacunek dla rezerwacji. Na przykład, jeśli ktoś ma umrzeć na raka, to niemożliwe, by np. przeszedł udar. Może się całować w usta z zadżumionymi (empestés), może szesnaście razy dziennie spocony skakać na główkę do zimnej wody, nie rozchoruje się na dżumę, nie dostanie zapalenia płuc!?²

Koncepcję przedstawiania korelacji między chorobami dla odzwierciedlenia uwarunkowań społecznych można odczytywać jako sieciowanie i łączenie zjawisk naturalnych (jakimi są choroby), żywych istot (od człowieka po różne drobnoustroje, wirusy i bakterie) oraz relacji społecznych. W ten sposób mamy powiązanie przyrody i społeczeństwa, ponieważ indywidualna wiedza społeczna i relacje mogą być wykorzystane w zastosowaniu do przyrody i odwrotnie, a to wskazuje na jedność istot żywych i materii nieożywionej jako całości, która tworzy przyrodę na Ziemi.

U Harariego siła, którą mają ludzie, jest źródłem zagrożenia dla całej planety, więc trzeba się zastanawiać, na ile zapobieganie głodowi, wojnom i chorobom, wraz z towarzyszącym im wzrostem gospodarczym, było zgodne z potrzebami Ziemi. $Z$ tego powodu autor uważa, że należy wybrać stabilność ekologiczną, by uniknąć katastrofy ${ }^{28}$. Nieśmiertelność jako niepożądana konsekwencja niesie za sobą pewne problemy ekologiczne dla ludzkości, innych istot żywych i całej planety.

\section{Deszcz jako zjawisko ekokrytyczne}

Przyroda (w najszerszym tego słowa znaczeniu) wraz ze wszystkimi różnorodnymi zjawiskami jest stosunkowo powszechna w twórczości literackiej. Wielu pisarzy wykorzystywało zjawiska naturalne takie jak deszcz, słońce, śnieg, wiatr do tworzenia atmosfery, poprzez symbolikę wyrażali stany, uczucia i wydarzenia albo w określony sposób włączali je do akcji w swoich dziełach. Ekokrytyka z definicji łączy naturę z literaturą, więc zjawiska przyrodnicze są interpretowane inaczej niż zwykła analiza symboli czy tła wydarzeń.

Oprócz śmierci, będącej podstawowym wątkiem powieści Pronalazak Athanatika, dla ekokrytycznej lektury ważne jest zjawisko naturalne - deszcz. Jedną z podstawowych zasad ekokrytyki może być powiązanie przyrody - w tym wszelkich zjawisk - $\mathrm{z}$ literaturą. W powieści kilkakrotnie pojawia się deszcz - zaczyna się od wzmianki o deszczowym popołudniu, podczas którego narrator siedzi z Krezubim w kawiarni. Desnica przez narratora opisuje deszcz, który pada równomiernie przez kilka dni. Myśli o deszczu jak o wodzie - skąd pochodzi, czy tworzy cykl, czy jest to nowa woda:

\footnotetext{
${ }^{27}$ Desnica, Pronalazak Athanatika, 15.

${ }^{28}$ Yuval Noah Harari, Homo deus. Kratka povijest sutrašnjice, tłum. Marija Perišić (Zagreb: Fokus komunikacije, 2017), 23-24.
} 
Czy to możliwe, że to zawsze nowa, nieużywana woda - ale skąd jej tak dużo! - lub czy to te same zapasy, raz już wykorzystane, płynące w zamkniętym kręgu, kanałami i wlotami, spływają do niektórych podziemnych punktów zbiorczych, gdzie są szybko filtrowane i oczyszczane, ponownie pompowane ku górze, a następnie oddolnie znów przelewane, odsączane, przeciekają... Jeśli tak właśnie jest, wtedy naprawdę, przy jakiejś nieprzewidzianej awarii maszyn, nie ma ratunku!... ${ }^{29}$

Powieść kończy się deszczem i jego miarowym opadem, „jakby od zawsze padało i jak gdyby padać miało wiecznie"30.

Desnica postrzega deszcz na kilku poziomach: a) symbolicznym, porównując go do upływu czasu jako constans, w którym wydarzenia się rozwijają lub nic się nie dzieje, niezależnie od tego (zarówno deszcz, jak i czas) płynie; b) na poziomie przyrodniczym lub technicznym, rozważając, jak powstaje i jak przebiega naturalny cykl obiegu wody w przyrodzie, postrzegając ten proces jako ciąg rozwiązań technicznych (punkty poboru, pompy, filtry); c) jako relacje między narratorem a deszczem, która jest „typowo barowa” i pokazuje związek między początkiem a końcem powieści, ponieważ deszcz pada przez cały czas trwania powieści.

Istotne wydaje się przyjrzenie się poziomowi technicznemu, czyli postrzeganiu deszczu jako systemu rozwiązań technicznych, służących do obiegu wody w przyrodzie. Takie podejście jest stopniowym wprowadzeniem do powieści, w której zostanie pokazany szczyt cywilizacji technologicznej, która stworzy athanatik. Ponadto przedstawienie deszczu jako rozwiązania technicznego, a nie zwykłego naturalnego cyklu pokazuje, że człowiek przyszłości z czasów athanatika nie postrzega zjawisk wokół siebie jako fenomenu przyrodniczego, co wskazuje na negację natury.

Zjawiska naturalne, takie jak deszcz, są stosunkowo powszechne w literaturze i niosą za sobą różną symbolikę. Wychodząc od koncepcji Susan Farrell, która na przykładzie lektury dzieła Pożegnanie z broniq amerykańskiego pisarza Ernesta Hemingwaya deszcz interpretuje w kontekście śmierci, deszcz u Desnicy nabiera nowego znaczenia nie tylko jako tło akcji powieści, ale także jako tło dla całej osi życia, śmierci i nieśmiertelności. Według Susan Farrell w powieści Pożegnanie z broniq powiązanie deszczu ze śmiercią można dostrzec na przykładach lęku przed deszczem i związanej z nim śmierci ${ }^{31}$. Najbardziej widoczne jest to w cytacie: „Boję się deszczu, ponieważ czasami widzę w nim siebie martwą - powiedziała mu - a czasami widzę ciebie martwego w nim" ${ }^{32}$.

Jeśli przyjmiemy ten model dla powieści Pronalazak Athanatika, pojawienie się deszczu na początku i na końcu utworu wskazuje na śmierć, a dokładniej na śmiertelność stojącą w tle powieści dialogowej i rozmów o nieśmiertelności między Krezubogiem a narratorem. Co więcej, słowa Desnicy o deszczu jako wartości stałej (,jakby od zawsze padało i jak gdyby padać

\footnotetext{
${ }^{29}$ Desnica, Pronalazak Athanatika, 7.

${ }^{30}$ Desnica, 80.

${ }^{31}$ Susan Farrell, Rainy Day Blues: we Role of Weather in "A Farewell to Arms", College of Charleston Blogs, http:// blogs.cofc.edu/hons110/'les/2011/10/Rain-in-Hemingway.pdf. Por. Ernest Hemingway, A Farewell to Arms (New York: Charles Scribner's Sons, 1929).

${ }^{32}$ Hemingway, A Farewell to Arms, 135. Tłum. G.Đ.
} 
miało wiecznie") dodatkowo ukonstytuują śmiertelność jako naturalną odpowiedź na ludzkie poszukiwanie nieśmiertelności. Jednocześnie Desnica wskazuje na problem „zepsucia i wyzwolenia” od deszczu, czym przypomina, że przyroda wraz ze swoim zjawiskiem, jakim jest deszcz, jest nie tylko kulisami, tłem fabuły książki oraz ludzkiego życia, ale aktywnym elementem, równym człowiekowi i stałą wartością w jego życiu, kształtując go jako część przyrody w kontakcie ze zjawiskami naturalnymi (tak deszczem, jak i śmiercią). W tym kontekście można by zinterpretować początek i koniec powieści, kiedy opisywany jest deszcz.

\section{Pronalazak Athanatika jako zapowiedź powieści dystopijnej dotyczącej środowiska/ekologii}

Współczesna literatura chorwacka nie obfituje w powieści związane z dystopijną ${ }^{33}$ przyszłością, którą determinują czynniki dotyczące środowiska/ekologii. Najbardziej reprezentatywnymi przykładami są powieści Planet Friedman Josipa Mlakicia i Mjesečev meridijan Edo Popovicia.

Akcja powieści Planet Friedman toczy się na zanieczyszczonej planecie, którą stała się Ziemia po zwyciężeniu doktryny ekonomicznej [Miltona - przyp. tłum.] Friedmana. Ludzie zostali podzieleni na kilka kategorii, a dokładnie grupy oraz strefy: A - uprzywilejowani, B - osoby, które mogą stać się uprzywilejowane, $C$ - osoby odrzucone. Wspomniane strefy są ściśle wydzielone. Główną postacią jest Gerhard Schmidt. Choć należy do elity, dzięki swojej pacjentce Pauli Bolt - osobie z niepełnosprawnościami, odnoszącej sukcesy sportowe - ma okazję zobaczyć pozostałe, ubogie grupy społeczne. W świecie bez emocji i książek, zdominowanym przez kapitalizm, korporacje (Vijeće dvadeset i pet koorporacija [Rada Dwudziestu Pięciu Korporacji], firmy takie jak Rosche i Natto) i reality show jako wyznacznik wartości, gdzie najważniejsze jest odniesienie sukcesu, Schmidt dzięki książkom Szekspira i Yeatsa (niedostępnym w strefie A, ponieważ nie przetrwały), które otrzymał od Pauli, odkrywa swój ludzki wymiar. Ważnym wątkiem jest związek Gerharda z jego ojcem Andreasem, który okazał człowieczeństwo na planecie Friedman, przekazując leki i szczepionki chorym oraz potrzebującym z niższej grupy (B), w czasie wielkiej grypy. Został ukarany i zabity za zbrodnię współczucia. Schmidt i Paula spotykają przywódcę rebeliantów Blacktootha, który drukuje i dystrybuuje książki, ale sam po zwycięstwie buntowników również ogranicza dostęp do nich i zostaje dyktatorem. Gerhard mówi o historii jako o polu magnetycznym z dwoma biegunami: rewolucji i kontrrewolucji. Planet Friedman kończy się wyjazdem Gerharda i Bruce'a, syna jego i Pauli, do bezpiecznego miejsca Ždralove izvore ${ }^{34}$.

Wiele odniesień w powieści dotyczy współczesnego świata i jego postaci. Na przykład najpotężniejszy człowiek nazywa się Steven Yobs. W ten sposób dystopijna przyszłość jest przeplatana z teraźniejszością. Powieść pokazuje globalny obraz, w którym się znajdujemy i my sami ${ }^{35}$.

\footnotetext{
${ }^{33} \mathrm{O}$ samych definicjach i rozbieżnościach Miranda Levanat-Peričić „Čitanje distopija iz aspekta različitih teorija žanra: Pavličić, Suvin, Frow”, w Komparativna povijest hrvatske književnosti. Vrsta ili žanr. Zbornik radova s XIX. međunarodnoga skupa održanog od 29. do 30. rujna 2016. godine u Splitu, red. Vinka Glunčić-Bužančić, Kristina Grgić (Split-Zagreb: Književni krug, 2017), 249-258.

${ }^{34}$ Josip Mlakić, Planet Friedman (Zagreb: Fraktura, 2012).

${ }^{35}$ Strahimir Primorac, „Imamo li komu slati poruke u boci?”, Vijenac, 21, nr 495 (2013), http://www.matica.hr/ vije-nac/495/imamo-li-komu-slati-poruke-u-boci-21432/.
} 
Powieść Edo Popovicia Mjesečev meridijan rozpoczyna się od opisu Mirko Grafa, członka komuny Korov, która zajmuje się ekologiczną uprawą produktów rolnych. Graf podróżuje do Zagrzebia, przedstawionego jako dystopijne miasto pełne grup społecznego marginesu bezdomnych, bezrobotnych, żebraków. Spotyka znajomego Josipa Pavlovicia, bezrobotnego, byłego pracownika SalarLab. W powieści ludzie dzielą się na dwie grupy, w zależności od podejścia do środowiska: Otrovani (Zatruci) - którzy zniszczyli środowisko - oraz Zaboravljeni (Zapomniani) - którzy mieszkają w Europie Środkowej, w swego rodzaju oazie nieskażonego środowiska, piją wodę ze strumienia, żywią się dzikimi zwierzętami i plonami. Głównymi bohaterami są dziewczyna Mila Salar - córka właściciela SalarLab, bogatego Zorana Salara, prowadząca projekt o Zapomnianych, czyli grupie wybranych kobiet i mężczyzn, którzy mają zamieszkać w odosobnionym miejscu jak prehistoryczni myśliwi i zbieracze - oraz młody mężczyzna Kaj, jeden z Zapomnianych, którego ojciec Jakub był odpowiedzialny za tworzenie opowieści o historii i życiu Zapomnianych. Powieść kończy się opowieścią Mirka o Dolinie Japod (Japodska dolina), gdzie żyje komuna, a w niej mieszkają Mila, Josip, Kaj i inni ${ }^{36}$. Utwór Popovicia ma również liczne odniesienia do współczesności, ponieważ zdarzenia wyimaginowane lub wyobrażone przeplatane są ze zdarzeniami, które nas dotknęły lub o których słyszeliśmy ${ }^{37}$.

Powieści Mjesečev meridijan i Planet Friedman oraz znacznie starszą Pronalazak Athanatika można porównywać na kilku płaszczyznach. Podobieństwa dostrzega się w samej przyczynie zmian, począwszy od ekologii, ochrony środowiska, a w zasadzie braku troski o nie (zanieczyszczenie, zniszczone środowisko, śmierć - nieśmiertelność). Autorzy tworzą ciąg przyczynowo-skutkowy, ponieważ zmiany ekologiczne, jako przyczyna, prowadzą do znaczących następstw w postaci zmian społecznych, przejawiających się w ściśle podzielonym na dwie (Desnica, Popović) lub trzy grupy (Mlakić) społeczeństwie. Ostateczną konsekwencją jest stworzenie totalitarnego świata, czy to $\mathrm{w}$ formie dyktatury zbliżonej do faszystowsko-nazistowskiej (prawica) albo pozbawionego skrupułów świata korporacyjno-kapitalistycznego (Mlakić, Popović). Projekcja ekologicznie zanieczyszczonej przyszłości i ludzkości, zmierzających ku upadkowi, jest uwarunkowana przez wrogów ówczesnych czasów (współczesności), dlatego obawy Vladana Desnicy skupiają się na możliwym powrocie nazizmu i faszyzmu, wówczas jeszcze dobrze pamiętanych. Natomiast Popović i Mlakić, współcześni pisarze, skupili się na negatywach bardzo aktualnego świata korporacyjnego i kapitalistycznego. Zestawiając, społeczeństwo według Mlakicia jest łącznikiem między społeczeństwem Desnicy i Popovicia, ponieważ w powieści oprócz korporacyjnego kapitalizmu wprowadza też dyktaturę, w której kontrolowana jest wiedza, emocje i życie jako całość zaprojektowane przez Stwórcę - Friedmana ${ }^{38}$. W ten sposób Mlakić pokazuje kulminację korporacyjnego kapitalizmu, który z konieczności przechodzi w dyktaturę, czyli totalitaryzm jako swój cel podstawowy.

\footnotetext{
${ }^{36}$ Edo Popović, Mjesečev meridijan (Zagreb: OceanMore, 2015).

${ }^{37}$ Strahimir Primorac, „Potraga za svijetom slobode”, Vijenac, 23, nr 561-562 (2015), http://www.matica.hr/vijenac/561\%20-\%20562/Potraga\%20za\%20svijetom\%20slobode/.

${ }^{38}$ Tea Šitum, Planet Friedman, Citajme.com (http://citajme.com/planet-friedman/).
} 
Wszyscy trzej autorzy wskazują na niemożność wyizolowania człowieka od przyrody oraz konsekwencje takiego podziału. Brak związku z naturą i oddalenie się od niej, stawianie za nadrzędne tworzenie kultury, cywilizacji i rozwoju prowadzą do problemów ekologicznych, które muszą wpływać na problemy społeczne. Można z tego wyciągnąć bardzo pesymistyczną wizję przyszłości, która jest dystopijna - zniszczona, odczłowieczona, nienaturalna i skierowana przeciwko przyrodzie. Zachowaniem ukierunkowanym przeciwko przyrodzie ludzie niweczą swoją własną przyszłość.

W drugiej warstwie możemy przeanalizować czas i miejsce akcji. Desnica i Mlakić tworzą znacznie bardziej niejasny świat, nie podają dokładnego roku ani szczegółowego opisu przestrzeni czy też obszaru, gdzie dzieje się akcja. Terytoria i przestrzenie są w rzeczywistości globalne i mogą być powiązane z różnymi krajami. Popović jest znacznie dokładniejszy w opisie miejsc (Zagrzeb, Dolina Japod), Chorwacja, Europa Środkowa), natomiast czas u niego jest nieokreślony, choć wiadomo, że dotyczy bliskiej przyszłości.

Cykl tematyczny nieśmiertelność: śmierć - życie jest punktem wspólnym dla wszystkich trzech autorów. Desnica zbudował całą swoją powieść wokół tematu nieśmiertelności i wynalezionego athanatika. Popović również porusza temat nieśmiertelności, ale marginalnie, najbardziej transparentnym u niego wątkiem jest powiązanie nieśmiertelności z pieniędzmi (kapitałem), a dokładniej z przeszczepem organów. Takie postrzeganie nieśmiertelności przybliża Popovicia do Harariego. U Mlakicia śmierć przedstawiona jest bez jakichkolwiek emocji i empatii. Wszystko postrzega przez pryzmat sukcesu, korzyści i chciwego nastawienia na własny zysk. U Popovicia i Mlakicia możemy mówić o śmiertelności, czyli o śmierci Ziemi z powodu długotrwałego zanieczyszczenia i problemów ekologicznych. Desnica przewiduje problem ekologiczny, biorąc pod uwagę niedobór żywności po wynalezieniu athanatiku. Wszyscy trzej autorzy poruszają wątek relacji nieśmiertelności jednostki wobec unicestwiania przyrody, co w dłuższej perspektywie prowadzi do wymarcia rodzaju ludzkiego.

Utwory możemy też analizować, opierając się na binarnych pojęciach wolności - dominacji. Wspólne dla wszystkich autorów jest stworzenie świata hegemonii i władzy, w którym uprzywilejowani (jeśli wyobrażamy sobie ich jako jedną grupa) dominują nad wszystkimi innymi, przy czym człowieczeństwo jako wartość całkowicie zanika w przyszłości budowanej - choć może lepszym określeniem jest burzonej - na problemach ekologicznych. Dlatego wolność jest najważniejszym pojęciem, z którym można definiować analizowane dzieła Desnicy, Mlakicia i Popovicia. Matko Vladanović pisze o powieści Popovicia: „U moru lažnih informacija, nametnutih i iskonstruiranih identiteta, manipulacija i propagande odgovor na pitanje slobode različit je za svakog pojedinca” [,W morzu fałszywych informacji, narzuconych i dekonstruowanych tożsamości, manipulacji i propagandy, odpowiedź na pytanie o wolność jest inna dla każdej jednostki"] ${ }^{39}$. Te słowa doskonale opisują pojęcie wolności w wymienionych utworach, niezależnie od indywidualnego zbioru cech poszczególnych postaci. Kwestia dominacji i wyższości w odniesieniu do binarnej kwestii wolności jest nierozerwalnie związana $z$ naturą i zniszczonym środowiskiem. We wszystkich trzech

\footnotetext{
${ }^{39}$ Matko Vladanović, „Edo Popović: Mjesečev meridijan”, Moderna vremena, http://www.mvinfo.hr/clanak/edo-
} po-povic-mjesecev-meridijan. 
dziełach dominacja człowieka (jako korporacyjnego, racjonalnego bytu technologicznego) stoi w sprzeczności z wolnością innych żywych podmiotów, ale także z wolnością człowieka (jednostki, która ma i tę drugą stronę: emocji i empatii, stanowiącą część naturalnej równowagi i cyklu życia).

W ślad za analizowaną wolnością i dominacją pojawia się pytanie o projekcje autorów dotyczące przyszłości i samego zakończenia każdej z powieści. Pod koniec swoich utworów Desnica i Mlakić przemawiają głosem optymistycznym: Desnica pisze o ostatecznym zniszczeniu athanatiku, a Mlakić tworzy nieskorumpowany świat (Ždralove izvore), miejsce nowego począt$\mathrm{ku}$ - choć nie bez dozy sceptycyzmu (otwarta kwestia wiadomości w butelce) ${ }^{40}$. Zakończenie Popovicia niesie optymistyczne przesłanki, ponieważ pozostawia miejsce na różne koncepcje wolności, definiowane zgodnie z potrzebami konkretnych postaci (podróże Kaji i Josipa, refleksje Mirko nad przyszłością i miejscami, do których możemy się udać i gdzie możemy się zatrzymać) ${ }^{41}$. Wspólną cechą każdego zakończenia tych powieści jest to, że optymizm tkwi w swoistym powrocie do natury - u Desnicy w zniszczeniu nienaturalnego athanatiku, który narusza naturalny porządek, u Mlakicia w przeniesieniu się do obszaru chronionego, czyli miejsca, w którym przyroda nie została zdegradowana, podobnie jak u Popovicia, w poszukiwaniu wolności i miejsc, gdzie natura pozostała nietknięta.

W pracy Death and the Anthropocene: Cormac McCarthy's World of Unliving Louise Squire opiera swój paradygmat metodologiczny na koncepcji Paula Crutzena o antropocenie, okresie geologicznym, w którym człowiek znacząco wpływa na geologiczne i zmiany środowiskowe, a także na postrzeganiu śmierci przez Jacques’a Derridę. Przedstawione idee (antropocen i śmierć) stawia w kontekście teorii literatury i analizy dzieła literackiego. Autorka bada literackie dzieło Cormaca McCarthy’ego, wykorzystując doświadczenie śmierci według Jacques’a Derridy, i rozważa: „Nauczyć się żyć, oznacza nauczyć się umierać, nauczyć się stawiać wszystko na jedną kartę, to znaczy akceptować absolutną śmiertelność (bez zbawienia, zmartwychwstania i odkupienia siebie oraz innych) [...] filozofować, to znaczy nauczyć się umierać" ${ }^{42}$. Dalej Squire zastanawia się, w jaki sposób koncepcje Derridy o śmierci i archiwum mają zastosowanie do dzieł literackich: „a) niemożność odkrywania granic śmierci jako takiej i b) refleksja na temat krajów, w których dekonstrukcja staje się odpowiedzialna za przyszłość poza doświadczeniem, przy czym antropocen może być czasem, w którym boimy się skazić archiwum wydarzeniami fizycznymi, dlatego dekonstruujemy (choć staramy się zrekonstruować) to, kim jesteśmy"43. Zadaje pytanie, czy koncepcję śmierci i antropocenu można połączyć oraz czy koncepcję archiwów Derridy jako matrycy można odczytać w wybranych utworach literackich (co sama czyni w pracach Cormaca McCarthy'ego). Łączenie ekokrytyki i dekonstrukcji jest otwartym zagadnieniem współczesnej metodologii ekokrytyki i tworzenia korelacji z postmodernizmem. Niezależnie od wspólnych korzeni w analizach poststrukturalistycznych, postmodernizm i ekokrytyka różnią się w części dotyczącej dekonstrukcji. Domagoj Brozović pisze o tym problemie w następujący sposób:

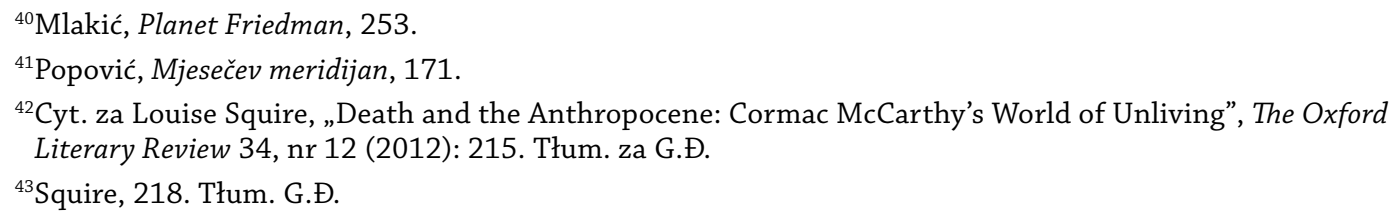


Tym, co odróżnia ekokrytykę od głównego nurtu poststrukturalizmu, jest rozwijanie świadomego sprzeciwu wobec postmodernistycznej inklinacji nieokiełznanej gry symbolicznej, językowej i kulturowej, przy czym zaleca się rekonstrukcyjne podejście do języka z wyraźnym osadzeniem w kontekście przyrody. Za pozornie głównym ekokrytycznym problemem związku środowiska z dyskursem wyłania się aksjomat o charakterze pozatekstowym i pozadyskursywnym, który otwarcie problematyzuje dekonstruktywne wymazanie relacji z rzeczywistymi referentami, co może skutkować poważnymi epistemologicznymi konsekwencjami dla współczesnej teorii literatury i kultury, a także motywować do rekonstrukcji pojęcia reprezentacji poetyckiej, którą postmodernizm traktuje a priori jako nieadekwatną. Ekokrytycznym wyzwaniem dla postmodernizmu i kluczowym pytaniem staje się, jak ponownie połączyć dyskursywność i materialność ${ }^{44}$.

Opinia Domagoja Brozovicia oraz autorów, na których się powołuje, jest jedną z możliwych interpretacji związku postmodernizmu z ekokrytyką ${ }^{45}$. Cytując Timothy'ego Morgana, który uważa, że dekonstrukcja jest cichym przyjacielem ekokrytyki ${ }^{46}$, uważam, że można stworzyć powiązanie ekokrytyki z postmodernizmem.

Idee Louise Squire dotyczące połączenia śmierci i koncepcji archiwów Derridy można zastosować do ekokrytycznej lektury wybranych dzieł Desnicy, Mlakicia i Popovicia. Katastrofa ekologiczna jest nieuniknioną konsekwencją działań człowieka w antropocenie, a zachowania w teraźniejszości i przyszłości będą tę sytuację potęgować. Czy warto żyć w światach opisanych w utworach Pronalazak Athanatika, Planet Friedman i Mjesečev meridijan? W światach różnego rodzaju terroru, kontroli i śledzenia, w których segregacje ludzi są wyjątkowo wyraźne i oczywiste? Ideę archiwum Derridy można odnaleźć w tych powieściach, zwłaszcza u Mlakicia i Popovicia, gdzie większość postaci nie jest w żaden sposób powiązana z przeszłością. Wyjątkiem są postacie anarchistów i ich przywódców, dalej Schmidta i Paula u Mlakicia, Zapomnianych oraz Mila i Mirko u Popovicia, pozwalają oni na wyjście z zanieczyszczonego świata i planety poprzez odwołanie do przeszłości i zachowanie określonych wartości z przeszłości takich jak książki, czytanie, emocje u Mlakicia lub życie w zgodzie z naturą jak u Popovicia. U Desnicy najbliżsi temu są „obserwatorzy”, jako zbiorowa nazwa ludzi, „którzy przeżywają historię i śledzą jej pogrzeb”" ${ }^{47}$ oraz członkowie herezji, którzy chcieli poznać prawdę. Właśnie nawiązania do przeszłości otwierały w utworach drogę do zmian i optymizmu. Uważam, że zerwanie powiązania z przyrodą nieuchronnie doprowadziło do zerwania z przeszłością i tradycją, co można odczytać w pesymizmie, który czeka nas w dystopijnej przyszłości. Źródłem optymizmu jest ponowne połączenie z naturą i odnowienie relacji z przeszłością. Ludzkie emocje, empatia, indywidualna odwaga, nadzieja i racjonalne podejście stworzyły przesłanki do lepszego życia w przyszłości.

\footnotetext{
${ }^{44}$ Brozović, Čitati zeleno, s. 31.

${ }^{45} \mathrm{O}$ różnych teoriach postmodernizmu wobec ekokrytyki por. Serpil Oppermann, „Theorizing Ecocriticism: Toward a Postmodern Ecocritical Practice", Interdisciplinary Studies in Literature and Environment, 13, nr 2, (2006), 103-128.

${ }^{46}$ Timothy Morton, „Deconstruction and / as Ecology”, w The Oxford Handbook of Ecocriticism, red. Greg Garrard (Oxford: Oxford University Press, 2014), 291-304.

${ }^{47}$ Desnica, Pronalazak Athanatika, 64.
} 


\section{Uwagi końcowe}

Ekokrytyczna lektura powieści Pronalazak Athanatika ukazuje dwa zjawiska naturalne, które przewijają się w powieści. Pierwsza to idea śmierci i nieśmiertelności, która jest kluczowym motywem powieści i centralną osią fabuły. Porównując i łącząc ${ }^{48}$ dzieła Vladana Desnicy i Yuvala Noaha Harariego, można zaobserwować, że obaj, analizując zakres nieśmiertelności, widzą wiele problemów, których ona dotyka, począwszy od środowiskowych, poprzez społeczne i ekonomiczne, do zmian politycznych. Niezależnie od różnic w osiąganiu nieśmiertelności - wynalazek medycyny u Desnicy i rozwiązania techniczne Harariego - obaj dochodzą do podobnych wniosków, przy czym uwarunkowana badaniami naukowymi nieśmiertelność ma szerokie konsekwencje w postaci zmian społecznych, które prowadzą do trwałych i niebezpiecznych konfliktów. Konflikty te mają swoje źródło w próbach człowieka stawiania się ponad przyrodą i innymi istotami żywymi, opartych wyłącznie na wymiarze technologicznym i tzw. rozwoju i postępie. Przyroda staje się obiektem drogi człowieka do supremacji, czego dowodem są próby osiągnięcia nieśmiertelności i znajdowania dla niej rozwiązań jako zwieńczenia sukcesu technologiczno-naukowego. Wynikająca z tego samowystarczalność człowieka nieuchronnie prowadzi do egzystencjalnego, a następnie społecznego kryzysu, w którym ten sam człowiek staje się przegranym, próbując przejąć kontrolę nad przyrodą, jednocześnie się jej sprzeniewierzając.

Kolejnym zjawiskiem analizowanym z punktu widzenia ekokrytyki jest naturalne występowanie deszczu. Myślę, że Desnica, ukazując deszcz na początku i na końcu powieści, pokazał kontrast dla rozmowy narratora i Krezuboga - dyskutują o nieśmiertelności - ponieważ deszcz, interpretowany zgodnie z tekstami Hemingwaya, oznacza śmierć, czyli w tym przypadku ludzką śmiertelność. Deszcz jest również pokazany jako problem techniczny, a nie zjawisko naturalne, odrzucając w ten sposób człowieka z czasów athanatiku, interpretuje zjawiska przyrodnicze i otaczający go świat wyłącznie za pomocą procesów technologicznych. Dodatkowo zaakcentowane zostało odcinanie się od człowieka i przyrody. Umiejscawiając deszcz na początku i końcu powieści, niezależnie od akcji, pisarz pośrednio ostrzega przed ciągłą śmiertelnością człowieka, ale ukazuje także przyrodę jako aktywny czynnik, a nie tylko kulisy w tle ludzkich działań.

Otwarte pozostaje pytanie, na ile Pronalazak Athanatika wpisuje się w gatunkową charakterystykę fikcji spekulatywnej według analizy Mirandy Levanat-Peričić, która stwierdza:

Świat alternatywny tych powieści jest dwukrotnie bardziej odległy od empirycznej rzeczywistości autora - przez czas w przyszłości i niezdefiniowanej narodowo przestrzeni kulturowej. Stąd metagatunkowość dystopii w literaturze chorwackiej widoczna jest też w tym, że powieść chorwacka przenosi historię przyszłości do innej tradycji literackiej, najczęściej tej, do której dystopia pierwotnie należy ${ }^{49}$.

\footnotetext{
${ }^{48} \mathrm{O}$ możliwości porównania i połączenia w naukach historycznych zob. Diego Olstein, Thinking History Globally (New York: Palgrave Macmillan, 2015), 59-98.

${ }^{49}$ Miranda Levanat-Peričić, „Metažanrovska obilježenost spekulativne fikcije u hrvatskoj književnosti: od Šufflaya do Mlakića", w Komparativna povijest hrvatske književnosti. Fantastika: problem zbilje. Zbornik radova sa XVIII. Međunarodnoga znanstvenog skupa održanog od 24. do 25. rujna 2015. godine u Splitu, red. Cvijeta Pavlović, Vinka Glunčić-Bužančić i Andrea Meyer-Fraatz (Split-Zagreb: Književni krug - Filozofski fakultet, Odsjek za komparativnu književnost, 2016), 316.
} 
Uważam, że Pronalazak Athanatika jest gatunkowo bliski akcji spekulacyjnej. O niezniszczalności przestrzeni zdarzeń i samego czasu świadczą wyznaczniki tej teorii. Powieść tę można zestawić z wieloma podobnymi, takimi jak Planet Friedman i Mjesečev meridijan. Oprócz wspólnej przyczyny wynikającej z problemów ze środowiskiem, istnieje widoczny podział społeczny na uprzywilejowanych - niezależnie od tego, czy są to nieśmiertelni, czy ci, którzy mają władzę społeczną bądź ekonomiczną - oraz wszystkich pozostałych. Ekologiczna przyczyna problemu niesie w konsekwencji zmiany społeczne i coraz większe i wyraźniejsze zróżnicowanie społeczne, kończące się systemami totalitarnymi - faszyzmem, nazizmem i kapitalizmem korporacyjnym w swoich odmianach.

Ciekawa jest koncepcja Desnicy o nieśmiertelności ludzi w odniesieniu do śmierci Ziemi jako planety - pokazanej u Popovicia i Mlakicia. Czy te dwie koncepcje można powiązać? Jaka jest maksymalna liczba ludzi, którzy mogą jednocześnie żyć na Ziemi? ${ }^{50}$ Jakie będą tego ekologiczne konsekwencje? ${ }^{51}$. W jakim stopniu ludzkie działanie i dążenie do władzy, w tym nieśmiertelności, przyczynią się do zagłady Ziemia jako planety? Jakie będą społeczne konsekwencje zmian środowiskowych, których jesteśmy świadkami (globalne ocieplenie, topnienie lodowców, pustynnienie, niszczycielskie burze, wojny o energię i wodę, zanieczyszczenie powietrza, wody i gleby, eksploatacja zasobów naturalnych itp.)? Te pytania są jedynie bodźcem do refleksji i dalszej pracy, zwłaszcza w kontekście sztucznej inteligencji, bioinżynierii i potencjalnej nieśmiertelności lub bezśmiertelności w przyszłości.

Znaczenie niedokończonej powieści Pronalazak Athanatika można dostrzec, jeśli zestawimy ją z bardzo aktualnymi tematami życia i śmierci (w rozumieniu dążenia do przezwyciężenia śmierci przez nieśmiertelność), a następnie ze sposobem myślenia o tej ostatniej. To z kolei jest bardzo ważne przy porównaniu z koncepcją Harariego, ale też z współczesnymi wyzwaniami śmierci i unikania jej. Desnicę można uznać za prekursora, który koreluje z aktualnymi rozważaniami naukowymi (Harari) i dziełami literackimi (Mlakić, Popović), ostrzegającymi, że czynniki dotyczące ekologii i środowiska (nieśmiertelność i wzrost populacji, niedobory żywności) mogą mieć poważny wpływ na zmiany społeczne, dystrybucję władzy i kształtowanie przyszłości. W ten sposób z dzieła literackiego, zdefiniowanego jako fikcja spekulatywna, powieść Pronalazak Athanatika stała się drogowskazem dla dającej się przewidzieć przyszłości i wyzwań, jakie niesie. Refleksje nad wyborami i podejście humanistyczne są zwrotem w kierunku lepszej i piękniejszej przyszłości całej ludzkości, świata istot żywych i Ziemi jako planety. Po przeanalizowaniu przywołanych w artykule dzieł można to uznać za wspólną refleksję Vladana Desnicy, Yuvala Harariego, Josipa Mlakicia i Edo Popovicia.

\section{Tłumaczyła Joanna Dobosiewicz}

\footnotetext{
${ }^{50}$ Według badania ONZ oczekiwany jest znaczący wzrost do 11,2 miliardów ludzi do 2100 roku. Por. World Population Prospects, The 2015 Revision. Ket findings and Advanced Tables, New York 2015, 2, https://esa.un.org/ unpd/wpp/publications/files/key_findings_wpp_2015.pdf.

${ }^{51}$ Por. Dražen Šimleša, Ekološki otisak. Kako je razvoj zgazio održivost (Zagreb: TIM Press, 2010).
} 


\section{Bibliografia}

Barry, Peter. Beginning Theory. An Introduction to Literary and Cultural Theory. Manchester-New York: Manchester University Press, 2009.

Borstelmann, Thomas. The 1970s. A New Global History from Civil Rights to Economic Inequality. Princeton: Princeton University Press, 2015.

Brozović, Domagoj. „Čitati zeleno. Ekokriticizam - neprepoznata mogućnost suvremene hrvatske znanosti o književnosti”. Književna smotra, 44, nr 164-165 (2012): 29-35.

Campbell Thompson, Reginald. The Epic of Gilgamesh: Complete Academic Translation, translated from cuneiform tablets in the British Museum literally into English hexameters, London 2007.

Cheng'en, Wu. A journey to the West. Beijing: Foreign Languages Press, 1955.

Desnica, Vladan. Pronalazak Athanatika. Zagreb: V.B.Z., 2006.

Đurđević, Goran. „Yuval Noah Harari, Sapiens: kratka povijest čovječanstva, Fokus, Zagreb 2015, 479", Historijski zbornik, 68, nr 1 (2015): 203-205.

Estok, Simon C. „Teorija s ruba: životinje, ekokritika, Shakespeare". Kazalište, 11, nr 35-36 (2008): 84-97 Choron, Jacques. "Death and Immortality”. W Dictionary of the History of Ideas. Zredagowane przez Philip P. Wiener, t. 1, 635-646. New York: Charles Scribner's Sons, 1974, https://web.archive. org/web/20070311081839/http://etext.lib. virginia.edu/cgi-local/DHI/dhi.cgi?id=dv1-76.

Farrell, Susan. Rainy Day Blues: we Role of Weather in „A Farewell to Arms”. College of Charleston Blogs, http://blogs.cofc.edu/ hons110/'les/2011/10/Rain-in-Hemingway.pdf.

Garrard, Greg. Ecocriticisam. Abingdon: Routledge, 2004.

Gladwin, Derek. „Ecocriticism”. W Oxford Bibliographies (http://www. oxfordbibliographies.com/view/document/ obo-9780190221911/obo-97801902219110014.xml).
Glotfelty, Cheryll. „Introduction: Literary Studies in an Age of Environmental Crisis”. W Ecocriticism Reader. Landmarks in Literary Ecology. Zredagowane przez Cheryll Glotfelty, Harold Fromm. Athens, Georgia: The University of Georgia Press, 1996.

Harari, Yuval Noah. Homo deus. Kratka povijest sutrašnjice. Przetłumaczone przez Marija Perišić. Zagreb: Fokus komunikacije, 2017, 23-24.

Harari, Yuval Noah. Sapiens. Kratka povijest čovječanstva. Zagreb: Fokus komunikacije, 2015.

Hemingway, Ernest. A Farewell to Arms (New York: Charles Scribner's Sons, 1929).

Horwath, William. „Some Principles of Ecocriticism". W Ecocriticism Reader. Landmarks in Literary Ecology. Zredagowane przez Cheryll Glotfelty, Harold Fromm. Athens, Georgia: The University of Georgia Press, 1996.

Kirša, Ingrid. „Likantropija u popularnoj kultury”. Diplomski rad. Sveučilište u Zagrebu, Hrvatski studiji, Odsjek za kroatologiju, 2017.

Kreober, Karl. „'Home at Grasmere': Ecological Holiness". Publications of the Modern Language Association of America, 89, nr 1 (1974): 132-141.

Levanat-Peričić, Miranda. „Čitanje distopija iz aspekta različitih teorija žanra: Pavličić, Suvin, Frow". W Komparativna povijest hrvatske književnosti. Vrsta ili žanr. Zbornik radova s XIX. međunarodnoga skupa održanog od 29. do 30. rujna 2016. godine u Splitu. Zredagowane przez Vinka Glunčić-Bužančić, Kristina Grgić, 249258. Split-Zagreb: Književni krug, 2017.

Levanat-Peričić, Miranda. „Metažanrovska obilježenost spekulativne fikcije u hrvatskoj književnosti: od Šufflaya do Mlakića”. W Komparativna povijest hrvatske književnosti. Fantastika: problem zbilje. Zbornik radova sa XVIII. Međunarodnoga znanstvenog skupa održanog od 24. do 25. rujna 2015. godine u Splitu. Zredagowane przez Cvijeta Pavlović, Vinka Glunčić-Bužančić i Andrea MeyerFraatz. Split-Zagreb:_Književni krug Filozofski fakultet, Odsjek za komparativnu književnost, 2016. 
Marjanić, Suzana. „Književni svjetovi s etnološkom, ekološkom i animalističkom nišom". Narodna umjetnost, 43, nr 2 (2006): 163-186.

Marjanić, Suzana. „Zoosfera Tita Andronika: ljudska, previše ljudska bestijalnost”. Treća, 10, nr 2 (2008): 59-82.

Mlakić, Josip. Planet Friedman. Zagreb: Fraktura, 2012.

Morton, Timothy. „Deconstruction and/ as Ecology”. W The Oxford Handbook of Ecocriticism. Zredagowane przez Greg Garrard, 291-304. Oxford: Oxford University Press, 2014

Nemec, Krešimir. „Pronalazak Athanatika između utopije i distopije”. W Vladan Desnica, Pronalazak Athanatika. Zagreb: V.B.Z., 2006.

Olstein, Diego. Thinking History Globally. New York: Palgrave Macmillan, 2015.

Oppermann, Serpil. „Theorizing Ecocriticism: Toward a Postmodern Ecocritical Practice". Interdisciplinary Studies in Literature and Environment, 13, nr 2, (2006): 103-128.

Popović, Edo. Mjesečev meridijan. Zagreb: OceanMore, 2015.

Primorac, Strahimir. „Imamo li komu slati poruke u boci?”. Vijenac, 21, nr 495 (2013), http://www.matica.hr/vije-nac/495/imamo-likomu-slati-poruke-u-boci-21432/.

Primorac, Strahimir. „Potraga za svijetom slobode". Vijenac, 23, nr 561-562 (2015), http://www.matica.hr/vije-nac/561\%20-\%20 562/Potraga\%20za\%20svijetom\%20slobode/.

Raspor, Tizian. Yuval Noah Harari, Homo deus. Kratka povijest sutrašnjice, prevela s engleskog Marija Perišić, Fokus komunikacije Zagreb 2017, 461. Historiografija.hr, http://www. historiografija.hr/?p=5663.

Rueckert, William. „Literature and Ecology: An Experiment in Ecocriticism". W Ecocriticism Reader. Landmarks in Literary Ecology. Zredagowane przez Cheryll Glotfelty, Harold
Fromm. Athens, Georgia: The University of Georgia Press, 1996.

Šimleša, Dražen. Ekološki otisak. Kako je razvoj zgazio održivost. Zagreb: TIM Press, 2010.

Squire, Louise. „Death and the Anthropocene: Cormac McCarthy's World of Unliving". The Oxford Literary Review, 34, nr 12 (2012): 215.

The Shock of the Global. The 1970s in Perspective. Zredagowane przez Niall Ferguson i in. Harvard: Harvard University Press, 2011.

Trček, Tjaša. „Ekokritika - upodobitve narave v izbranih mladinskih delih”. Diplomski rad. Univerza v Ljubljani, Pedagoška fakulteta, 2016.

Vladanović, Matko. „Edo Popović: Mjesečev meridijan". Moderna vremena, http://www. mvinfo.hr/clanak/edo-po-povic-mjesecevmeridijan.

World Population Prospects, The 2015 Revision. Ket findings and Advanced Tables. New York 2015, https://esa.un.org/unpd/wpp/publications/ files/key_findings_wpp_2015.pdf. 


\section{SŁOWA KLUCZOWE:}

\section{Vladan Desnica}

\section{ekokrytyka}

\section{P OWIEŚ CI C HORWACKIE}

\section{ABSTRAKT:}

Autor podejmuje się lektury krótkiej niedokończonej powieści Vladana Desnicy Pronalazak Athanatika z niszowej perspektywy ekokrytycznej. Artykuł składa się z trzech części tematycznych: ekokrytycznego ujęcia cyklu tematycznego: życie - śmierć - nieśmiertelność w porównaniu i nawiązaniu do dzieła Homo deus Yuvala Noaha Harariego. Następnie autor ekokrytycznie analizuje deszcz poprzez pryzmat koncepcji Susan Farrell. W ostatniej części analizuje utwór Pronalazak Athanatika w kontekście dystopijnych współczesnych chorwackich powieści ekologicznych/dotyczących środowiska: powieści Planet Friedman Josipa Mlakicia oraz książki Mjesečev meridijan Edo Popovicia, w odniesieniu do ekokrytycznych tekstów Louise Squire. Autor konkluduje, że Desnica w swoim dziele Pronalazak Athanatika - które zalicza do fikcji spekulatywnej - odwoływał się do aktualnych rozważań naukowych (Harari) i dzieł literackich (Mlakić, Popović). Ostrzegał, że ekologia i czynniki ekologiczne - nieśmiertelność i wzrost populacji, brak żywności, a w ostateczności niszczenie planety - mogą mieć destrukcyjny wpływ na zmiany społeczne, dystrybucję władzy i kształtowanie przyszłości. Desnica stał się dzięki temu prekursorem powieści ekologicznych. 


\title{
dystopia
}

\author{
H U M A N I S T Y K A \\ Ś R O D O W I K OW A
}

\section{NOTA O AUTORZE:}

Goran Đurđević - chorwacki archeolog, historyk starożytności i środowiska zatrudniony jako profesor na Pekińskim Uniwersytecie Studiów Międzynarodowych. Odbył studia w Chorwacji (Zadar), Indiach (Uniwersytet w Bombaju), Chinach (Stołeczny Zwyczajny Uniwersytet w Pekinie) i w Stanach Zjednoczonych (UCLA) z archeologii, historii i mitologii porównawczej. Otrzymał tytuł doktora na Stołecznym Zwyczajnym Uniwersytecie w Pekinie w 2021 r. (rozprawa Refleksja w sztuce okresu Qin - Han i w sztuce rzymskiej - studium porównawcze na temat starożytnych luster). Prowadzi badania w trzech obszarach: światowa starożytna archeologia porównawcza, humanistyka cyfrowa, humanistyka środowiskowa. 